Int. J. Adv. Eng. Pure Sci., Special Issue-I: e56-e65

DOI: $10.7240 /$ jeps.497033

RESEARCH ARTICLE / ARAŞTIRMA MAKALESI

\title{
Diamonyum Hidrojen Fosfatın Akışkan Yataklı Kristalizörde Büyüme ve Çözünme Hızına L-Prolin ve L-Asparajin Amino Asitlerinin Etkisinin İncelenmesi
}

\author{
Investigation of the Effects of L-Proline and L-Asparagine Amino Acids on the \\ Growth and Dissolution Rate of Diammonium Hydrogen Phosphate in Fluidized \\ Bed Crystallizer
}

\author{
Aybala GENÇASLAN ${ }^{1}$, Berçem KIRAN-YILDIRIM ${ }^{1}{ }^{\mathbb{D}}$, Sibel TITIZ-SARGUT ${ }^{1}$ (D) \\ ${ }^{1}$ Marmara Üniversitesi, Kimya Mühendisliği Bölümü, 34722, Kadıköy/İstanbul, TÜRKIYE
}

Öz

Diamonyum hidrojen fosfat kristallerinin büyüme ve çözünme hızları akışkan yataklı kristalizörde incelenmiştir. Deneyler, saf ortamda ve amino asitlerin farklı derişimlerde kullanıldığı koşullarda yapılmıştır. Amino asit katkısı olarak L-prolin ve L-asparajin kullanılmıştır. Büyüme hızı, aşırı doygunluk seviyelerine göre değerlendirilmiştir. Elde edilen sonuçlar incelendiğinde, L-prolin ve L-asparajin varlığında diamonyum hidrojen fosfat kristallerinin büyüme hızlarının saf ortama göre az da olsa bastırıldığı, buna karşılık çözünme hızlarının belirgin bir şekilde azaldığı tespit edilmiştir. Difüzyon ve entegrasyon olarak iki direncin kristal büyümesi üzerindeki bağıl etkinliğini değerlendirmek üzere, büyüme hızı verileri kullanılarak Damköhler sayıları ve etkinlik faktörleri hesaplanmıştır. Etkinlik faktörü sonuçlarına göre, hem saf ortamda hem de amino asit katk1lı ortamlarda diamonyum hidrojen fosfat kristallerinin büyümesini kontrol eden mekanizmaya difüzyon ve entegrasyon adımlarının birlikte katkı sağladığı görülmüştür. Ancak saf ortamda entegrasyonun biraz daha yüksek etkiye sahip olduğu saptanmıştır. Bununla birlikte amino asitlerin varlığında, difüzyon basamağının etkinliğinin saf ortamdakine göre biraz daha arttığı görülmüştür. Bu artış, L-prolin amino asitinin en yüksek konsantrasyonunda en belirgin şekilde olmuştur. Ayrıca, 1ş1k mikroskopunda çekilen görüntülerden, amino asitlerin varlığında büyüyen diamonyum hidrojen fosfat kristallerinin morfolojisinin saf ortama göre belirgin şekilde değiştiği görülmüştür.

Anahtar Kelimeler: Akışkan yatak kristalizör, Diamonyum hidrojen fosfat, Amino asitler, Etkinlik faktörü, Damköhler sayısı, Difüzyon ve entegrasyon adımları.

\begin{abstract}
The growth and dissolution rates of diammonium hydrogen phosphate crystals were investigated in a fluidized bed crystallizer. The experiments were carried out in pure media and in the presence of the amino acids at the different concentration levels. L-proline and L-asparagine amino acids were used as additives. The growth rate was evaluated according to supersaturation levels. The results show that the growth rates of diammonium hydrogen phosphate crystals in the presence of L-proline and L-asparagine are slightly suppressed compared to the pure medium, while dissolution rates are significantly reduced. Damköhler numbers and efficiency factors are calculated by using the growth rate data in order to evaluate the relative effectiveness of diffusion and integration resistances on crystal growth. According to the efficiency factor results, it is revealed that both diffusion and integration steps contributed to the growth controlling mechanism of diammonium hydrogen phosphate crystals in pure media and in the presence of amino acids. But, it is determined that efficiency of integration step is slightly higher than efficiency of diffusion step in the pure media. However, it is found that efficiency of the diffusion step in the presence of amino acids slightly increase in comparison with the pure media. This effect is observed prominently in the highest concentration of L-proline amino acid. In addition, it is seen from images taken in the optical microscope that the morphology of diammonium hydrogen phosphate crystals growing in the presence of amino acids significantly change.
\end{abstract}

Keywords: Fluidized bed crystallizer, Diammonium hydrogen phosphate, Amino acids, Effectiveness factor, Damköhler number, Diffusion and integration steps.

Sorumlu yazar/Corresponding Author: Aybala GENÇASLAN, Tel: +90 (216) 3480292 / 7I 9, e-posta: aybala.gencaslan@marun.edu.tr

Gönderilme/Submitted: |3.12.20I8, Düzenleme/Revised: II.02.20I9, Kabul/Accepted: 14.03.2019 


\section{I.GİRIŞ}

Suda çözünebilir amonyum fosfat tuzlarından birisi olan diamonyum hidrojen fosfat (DAP, $\left.\left(\mathrm{NH}_{4}\right)_{2} \mathrm{HPO}_{4}\right)$, bünyesindeki amonyak ve fosforik asidi kolayca toprağa bırakabilmesi nedeniyle, azot ve fosfor kaynağı gübre olarak yaygın bir kullanım alanına sahiptir. DAP, gübre olarak kullanımı haricinde şarap ve bira üretiminde mayanın fermantasyon gücünü arttırmak amacıyla katkı maddesi olarak ve alev geciktirici olarak da kullanılmaktadır [1].

DAP tuzu, \% 18 oranında azot ve $\% 46$ oranında fosfor içermektedir. İçerdiği fosforun \% 90’^ndan fazlası suda çözünebilmektedir. $\mathrm{Bu}$ nedenle toprağa verildikten sonra gerekli nemi bulduğunda DAP gübresinin içeriğindeki fosfor ve azot, bitkiler için kolayca yararlandıkları besinler olmaktadır [2]. DAP'ın zengin besin içeriğinin yanı sıra gübre olarak tercih edilmesinin bir diğer nedeni ise uygun fiziksel özelliklere (tane boyutu, şekli, döküm yoğunluğu vb.) sahip olduğu durumda senelerce uygun bir depoda topaklaşmadan saklanabilmesidir. Bu da diğer gübrelere kıyasla nakliye, depolama ve işçilik açısından büyük tasarruf sağlayabilmektedir. Bu nedenle üretilen diamonyum hidrojen fosfatın gübre olarak kullanılabilmesi için belirli kriterlere uygun olması gerekmektedir. Uygun fiziksel özelliklere sahip DAP üretimi de, üretim koşullarının, ortam stokiometrisinin ve katkıların etkisi ile yönlendirilebilmektedir. Bilindiği üzere granül halde üretimde, ürün kalitesini belirleyen en önemli fiziksel özelliklerden birisi tane boyut dağılımıdır. Ürün tane dağılımını belirleyen iki mekanizma, nükleasyon ve büyüme hız kademeleridir. Bu iki kademeye bağlı olarak ürün tane dağılımı oluşmaktadır. Dolayısı ile üretim ortamında bulunacak olan katkı maddelerinin ürün fiziksel özelliklerini ve tane dağılımını ne şekilde etkileyeceğini belirleyebilmek için nükleasyon, büyüme ve çözünme hız mekanizmalarının incelenmesi gerekmektedir.

Yapılan bu çalışmada DAP'ın büyüme ve çözünme hızlarına tane boyutunun ve katkı maddesi olarak seçilen prolin ve asparajin amino asitlerinin etkisi 250, 500 ve 1000 ppm amino asit konsantrasyonları için akışkan yataklı kristalizörde incelenmiştir. Kristal büyüme ve çözünme hızı ölçümleri Mullin tarafindan geliştirilen diferansiyel yönteme göre yapılmıştır. Farklı aşırı doymuşluk ve doymamışlıklarda yürütülen bu deneyler sonucunda, diamonyum hidrojen fosfat kristallerinin mikroskop altında fotoğrafları çekilerek, amino asitlerin kristal şekline olan etkisi de ayrıca belirlenmiştir.

Deneylerde katkı maddesi olarak amino asitlerin seçimi, amino asitlerin tarım topraklarında mikrobiyal flora dengesi, iyi bir organik madde mineralizasyonu ve aynı zamanda iyi bir toprak yapısı içinde köklerin gelişmesinde ve dağılmasında etkin madde olmaları esasına dayanılarak yapılmıştır. Literatürde amino asitlerin bitkisel hormonları ve büyüme düzenleyicileri uyaran ve aktive eden aktivatörler olduğu, çiçek ve meyve ile ilgili hormonların sentezini tetiklediği, polen doğurganlığına yardımcı olduğu ve bitkilerde hücre duvarlarını güçlendirdiği belirtilmektedir [3]. $\mathrm{Bu}$ çalışma için seçilen asparajin ve prolin amino asitleri, bitkilerde azot birikimini teşvik eden önemli amino asitlerdir. Hücredeki şeker dengesinin ayarlanmasında asparagin önemli rol oynamaktadır [4]. Prolin, gelişen bitki hücrelerinin osmotik hasardan korunmasında birincil işleve sahiptir. Ayrıca bitkilerin gelişimi sırasında sinyal molekülü olarak hareket ederek protein sentezinde düzenleyici işlev yapmaktadır [5]. Proteinlerin temel yapısını oluşturan amino asitlerin insan vücudu için gerekli besin maddeleri arasında olduğu, 20 çeşit temel amino asit arasında 10 amino asit çeşidinin insan vücudu tarafından ihtiyacı karşılayacak düzeyde sentezlenemedikleri için dışarıdan beslenme yolu ile alınmaları gerektiği literatürde verilen bilgiler arasındadır [6]. Dolayısı ile gübre olarak kullanım amaçlı DAP üretiminde katkı maddesi olarak amino asit kullanımı, toprak, bitki ve dolaylı olarak insan ve hayvan sağlığına olumsuz bir etki yapmayacaktır.

\section{II.TEORİ}

Büyüyen bir kristalin yüzeyinde katı birikiminde difüzyonal proseslerin etkili olduğunu ilk defa öne süren Noyes ve Whitney (1897) tarafindan ortaya atılan difüzyon teorileri, Berthoud (1912) ve Valeton (1924) tarafindan modifiye edilerek kütle birikiminin iki temel basamakta gerçekleştiği önerilmiştir (Şekil 1). Buna göre ilk basamakta; sıvı fazdan kristal yüzeyine kristal yapı taşlarının (iyonların veya moleküllerin) aktarımı (difüzyon basamağı), ikinci basamakta ise; difüzlenen yapı taşlarının kristal yapısına katılması (entegrasyon basamağı) gerçekleşmektedir. Difüzyon ve entegrasyon basamakları farklı konsantrasyon itici güçleri altında oluşurlar ve aşağıda verilen eşitliklerle açıklanırlar [7]:

$$
\begin{array}{ll}
\mathrm{R}_{\mathrm{G}}=\mathrm{k}_{\mathrm{d}}\left(\mathrm{C}_{\mathrm{b}}-\mathrm{C}_{\mathrm{i}}\right) & \text { (Difüzyon Aşaması) } \\
\mathrm{R}_{\mathrm{G}}=\mathrm{k}_{\mathrm{r}}\left(\mathrm{C}_{\mathrm{i}}-\mathrm{C}^{*}\right)^{\mathrm{r}} & \text { (Entegrasyon Aşaması) }
\end{array}
$$

Arayüzey derişimini $\left(\mathrm{C}_{\mathrm{i}}\right)$ ölçme zorluğu nedeniyle Eşitlik (1) ve (2)'nin pratikte kullanımı zordur. Bu nedenle toplam derişim farkı $\left(\mathrm{C}_{\mathrm{b}}-\mathrm{C}^{*}\right)$ göz önüne alınarak, kristal için toplam büyüme hız eşitliği (Eşitlik (3)) ifade edilmektedir. $\left(\mathrm{C}_{\mathrm{b}}-\mathrm{C}^{*}\right)$ ifadesi, aşırı doygunluk olarak da adlandırılmakta$\operatorname{dir}(=\Delta \mathrm{C})[8]$.

$$
\mathrm{R}_{\mathrm{G}}=\mathrm{k}_{\mathrm{g}}\left(\mathrm{C}_{\mathrm{b}}-\mathrm{C}^{*}\right)^{\mathrm{g}} \quad \text { (Toplam Büyüme Hızı) }
$$




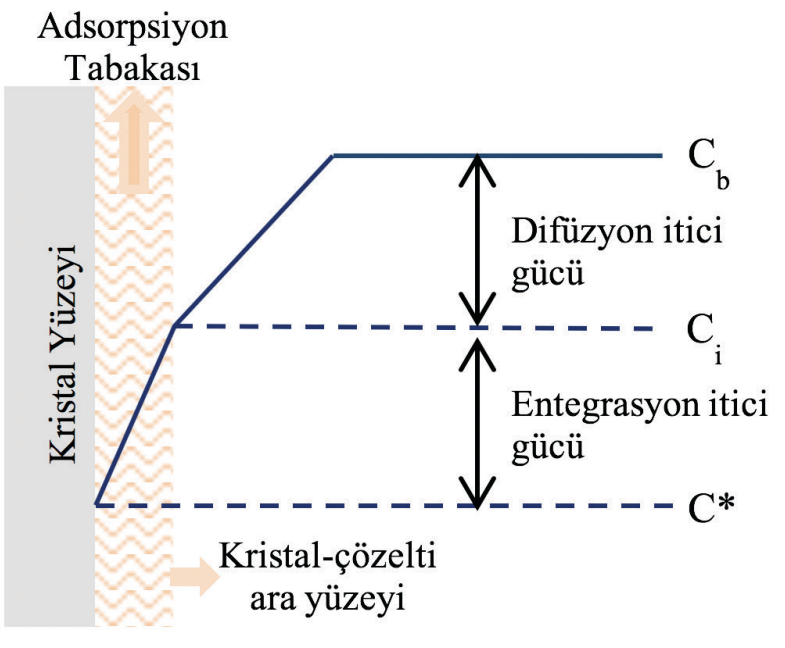

Şekil 1. Kristal Yüzeyindeki Konsantrasyon Değişimleri [9]

Eşitlik (1) ve (2)'deki arayüzey derişimleri elimine edilerek tekrar düzenlendiğinde elde edilen Eşitlik (4) kullanılarak toplam büyüme hızı, yüzey entegrasyon derecesi (r) ve hız sabiti $\left(\mathrm{k}_{\mathrm{r}}\right)$ hesaplanabilmektedir.

$R_{G}=k_{f}\left[\left(C_{b}-C^{*}\right)-\frac{R_{G}}{k_{s}}\right]^{\mathrm{T}}$

Burada $R_{G}$ ve $\left(C_{b}-C^{*}\right)$ değerleri deneysel olarak elde edilirken; $\mathrm{k}_{\mathrm{d}}$, Eşitlik (5) kullanılarak hesaplanır. Genel yaklaşım olarak $\mathrm{k}_{\mathrm{d}}$ hesaplanırken, çözünmenin sadece difüzyon kontrollü olduğu ve yüzey olaylarının büyümedeki kadar etkin olmadığı dikkate alınır [10].

$$
\mathrm{R}_{\mathrm{D}}=\mathrm{k}_{\mathrm{d}}\left(\mathrm{C}^{*}-\mathrm{C}_{\mathrm{b}}\right)
$$

Büyüme üzerinde difüzyon veya entegrasyon kontrol derecesinin kantitatif ölçüsü olarak etkinlik faktörü kavramı tanımlanmıştır. Entegrasyon etkinlik faktörü $\left(\eta_{\mathrm{r}}\right)$, Da sayısına bağlı olarak Eşitlik (6) ile ifade edilmektedir. Bu eşitliğe göre, entegrasyon etkinlik faktörünün, 1'e yakın değerlerinde kristal büyümesini kontrol eden adım yüzey entegrasyonu iken; 0'a yakın değerlerinde ise difüzyondur.

$$
\eta_{\mathrm{r}}=\left(1-\eta_{\mathrm{r}} \mathrm{Da}\right)^{\mathrm{r}}
$$

Damköhler sayısı genel anlam olarak, entegrasyonun difüzyona oranı şeklinde ifade edilebilir.

$\mathrm{Da}=\frac{\mathrm{k}_{\mathrm{s}}}{\mathrm{k}_{\mathrm{d}}}\left(\mathrm{C}_{\mathrm{b}}-\mathrm{C}^{*}\right)^{\mathrm{T}-1}$

Difüzyon etkinlik faktörü $\left(\eta_{\mathrm{d}}\right)$ de Eşitlik (8)'deki ifadeyle gösterilmektedir.

$$
\eta_{\mathrm{d}}=\mathrm{Da}\left(1-\eta_{\mathrm{d}}\right)^{\mathrm{r}}
$$

\section{MATERYAL VE YÖNTEM}

\subsection{Akışkan Yatak Kristalizörde Büyüme Hızı Ölçüm Yöntemleri}

Gerçek kristalizör şartlarına en yakın koşullar altında çalışıldığ 1 için çok fazla tercih edilen akışkan yatak kristalizöründe, kristal büyüme hızı ölçümleri Mullin tarafından geliştirilen iki farklı yöntemle yapılmaktadır. Bunlar, diferansiyel ve entegral yöntemlerdir [7]. Bu çalışmada büyüme ve çözünme hızı ölçümleri diferansiyel yönteme göre yapılmıştır.

Diferansiyel yönteme göre akışkan yataklı kristalizörde büyüme hızı ölçülürken, sistemde nükleasyonun olmadığı, büyüme hücresine konulan ve hücreden alınan kristallerin sayısının aynı olduğu, bütün kristallerin aynı boyuta ve aynı hacim şekil faktörüne sahip olduğu, bütün kristallerin aynı oranda büyüdüğü ve çözündüğü kabul edilmektedir. Yapılan bu kabuller sonucunda, akışkan yatak büyüme hücresine konulan $\mathrm{N}$ adet kristalin miktarı ve tane boyutu (sirasiyla $\mathrm{m}_{1}$ ve $\mathrm{L}_{1}$ ) ile hücreden alınan $\mathrm{N}$ adet kristalin miktarı ve tane bo-

\begin{tabular}{|c|c|c|c|c|}
\hline $\begin{aligned} \text { Büyüme } & \\
\mathrm{m}_{1} & =\alpha \rho \mathrm{L}_{1}^{3}\end{aligned}$ & hücresine & konulan & kristal & $\begin{array}{l}\text { miktar1, } \\
(9)\end{array}$ \\
\hline $\begin{array}{c}\text { Büyüme } \\
\mathrm{m}_{2}=\alpha \rho \mathrm{L}_{2}^{3}\end{array}$ & hücresinden & alınan & kristal & $\begin{array}{l}\text { miktar1, } \\
(10)\end{array}$ \\
\hline
\end{tabular}
yutu (sirasılyla $\mathrm{m}_{2}$ ve $\mathrm{L}_{2}$ ) değerlendirilerek, kristal büyüme hızı/çözünme hızı Eşitlik (13)'e göre hesaplanır.

$\Delta \mathrm{L}=\mathrm{L}_{2}-\mathrm{L}_{1}=\mathrm{L}_{1}\left(\frac{\mathrm{m}_{2}}{\mathrm{~m}_{1}}\right)^{\frac{1}{3}}-1$

Lineer büyüme hızı,

$\mathrm{G}=\frac{\Delta \mathrm{I}}{\mathrm{t}}$

$\mathrm{G}=\frac{\mathrm{I}_{1}}{\mathrm{t}}\left[\left(\frac{\mathrm{m}_{2}}{\mathrm{~m}_{1}}\right)^{1 / 3}-1\right]$

biçiminde hesaplanır. Eşitlik (14)'te Lineer büyüme hızı (G) ile toplam kütlesel büyüme hızı $\left(\mathrm{R}_{\mathrm{G}}\right)$ arasındaki ilişki ifade edilmektedir.

$\mathrm{R}_{\mathrm{G}}=3 \frac{\alpha}{\beta} \rho_{\mathrm{c}} \mathrm{G}$

Bu çalışmada Eşitlik 14'te yer alan hacim ve yüzey şekil faktörleri (sırasıyla a ve b) için kristal şeklinin küresel olduğu kabulü yapılmıştır. Küresel partiküller için $a=\pi / 6, b=\pi$ değerleri alınarak toplam kütle büyüme hızı $\left(\mathrm{R}_{\mathrm{G}}\right)$ hesaplanmıştır [11]. 


\subsection{Deney Sistemi}

Çalışmada kullanılan akışkan yataklı kristalizör Şekil 2'de gösterilmektedir. Sistem tamamen camdan yapılmış olup 20 litrelik çözelti depolama tankına sahiptir. Tankta bulunan çözelti santrifüj pompa ile sürekli olarak sistemde döngü halinde tutulmaktadır. Kullanılan akışkanlaştırma hücresi, 200 mm yüksekliğinde ve $12 \mathrm{~mm}$ iç çapındadır. Hücre içerisine konulan kristallerde herhangi bir kayıp olmaması için hücrenin alt ve üst kısımları metal elek teli ile kapatılmıştır. Hücre içerisine her deney için $2.5 \mathrm{~g} \pm 10 \mathrm{mg}$ incelenecek elek fraksiyonuna sahip saf DAP kristalleri konularak, sabit bir akışkanlaştırma hızında deneyler yürütülmüştür. Deneyler sırasında gerekli aşırı doygunluk, hücreden geçen çözelti sıcaklığının, bir ısı değiştiricisi yardımıyla doygunluk sıcaklığının altına düşürülmesi ile elde edilmiştir. Deneyler sırasında sistemde nükleasyonun oluşmaması için sabit sıcaklıktaki bir termostat yardımıyla tanktaki çözelti sıcaklığının, doygunluk sıcaklığının üstünde tutulması sağlanmıştır. Her bir deney 12 dakika sürdürülmüş ve hücreden geçen çözelti sıcaklığı bir dakikalık aralıklarla $\pm 0.1{ }^{\circ} \mathrm{C}$ hassasiyetli pt100 termo elemanlı sıcaklık ölçer yardımı ile ölçülmüştür. Ölçülen sıcaklıkların ortalaması, kristal büyüme hızı hesaplamalarında esas olarak alınmıştır.

Çözünme deneylerinin yapılması için gerekli olan doymamışlık ise, doygunluk sıcaklığının üzerindeki sıcaklıklarda çalışılarak sağlanmıştır. Her bir deney sonunda, hücreden alınan kristaller süzülmüş havada kurutulduktan sonra tartılıp, Eşitlik (13)'e göre büyüme ve çözünme hızları hesaplanmıştır.

Deneyler saf ortamda ve seçilen aminoasitlerinin (prolin ve asparajin) farklı konsantrasyonlarında (250 ppm, 500 ppm, ve 1000 ppm) yürütülmüştür. Saf ortamda yürütülen deneylerde $-710+600 \mu \mathrm{m}$ ile $-600+500 \mu \mathrm{m}$ tane boyutları kullanılmıştır. Amino asitlerin DAP'ın büyüme ve çözünme hızına etkisinin incelendiği deneylerde ise tane boyutu olarak - 710+600 $\mu \mathrm{m}$ seçilmiştir. Ayrıca numunelerin 2.5x optik mikroskop görüntüleri Olympus $\mathrm{CH} 20$ cihazıyla alınmıştır.

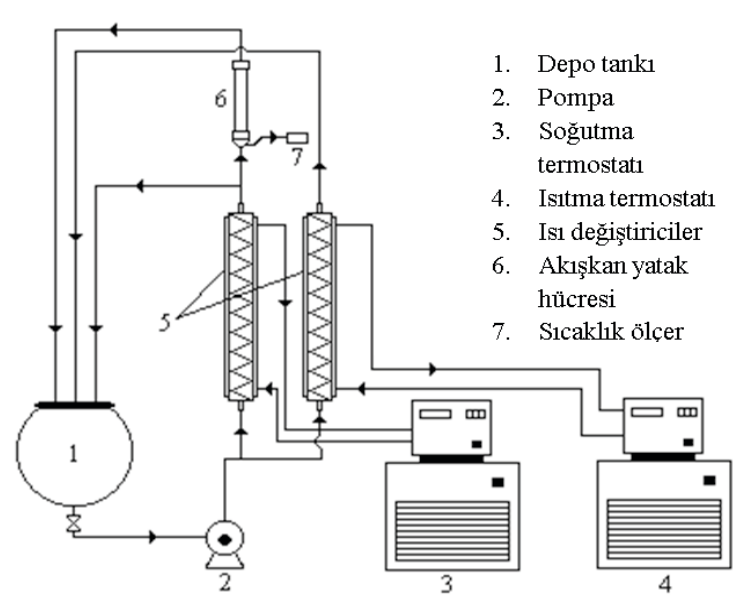

Şekil 2. Deney Düzeneği

\section{III.BULGULAR VE TARTIŞMA}

Deneylerde DAP kristallerinin saf ortamda ve farkl1 konsantrasyonlarda prolin ve asparajin amino asitleri varlığında büyüme ve çözünme hızları ölçülmüştür. Saf ortamda yapılan deneylerde $-710+600 \mu \mathrm{m}$ ve $-600+500 \mu \mathrm{m}$ boyutlarındaki DAP kristalleri kullanılmıştır. Elde edilen sonuçlar Şekil 3'te verilmiştir.

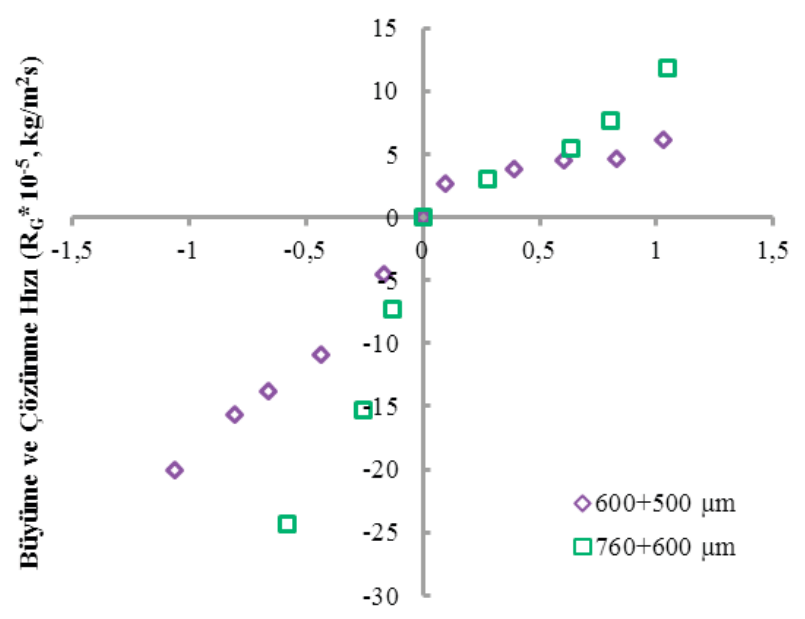

Așırı Doygunluk, $\Delta \mathrm{C}$ (g DAP/100 g çözelti)

Şekil 3. Saf ortamda $-710+600 \mu \mathrm{m}$ ve $-600+500 \mu \mathrm{m}$ kristal boyutu için büyüme ve çözünme hızının aşırı doygunluk ile değişimi

Şekil 3'ten de görüldüğü üzere, DAP kristallerinin büyüme hızları boyuta bağlı olarak önemli bir değişim göstermezken; çözünme hızları, tane boyutunun artmasıyla artmaktadır. Genel olarak, tane boyutu küçüldükçe yüzey alanı artacağından, çözünme hızının da artması beklenen bir durumdur. Akışkan ile 
katı taneciklerin temas alanı artacağından, çözünme de daha etkin bir şekilde gerçekleşecektir. Ancak burada çözünme bölgesinde yer alan kristallerin yüzey kalitesinin, çözünme hızlarını etkileyen önemli bir faktör olduğu göz önünde bulundurulmalıdır. Özellikle çözünme hız ölçümlerinde kullanılan kristallerin dış yüzeylerindeki farklılıklar, yüzeylerdeki mevcut girinti ve çıkıntılar, çözünme hızlarını doğrudan etkileyen faktörlerdir.

DAP kristallerinin toplam büyüme hızının aşırı doygunlukla değişimi Eşitlik (3) kullanılarak iki farklı tane boyut aralığı için belirlenmiştir. Elde edilen eşitlikler aşağıda verilmiştir. Burada Eşitlik (15), $-600+500 \mu \mathrm{m}$ boyut aralığ için; Eşitlik (16) ise, $-710+600 \mu \mathrm{m}$ boyut aralığı için elde edilen eşitliklerdir.

$$
\begin{aligned}
& \mathrm{R}_{\mathrm{G}}=1.04 * 10^{-4}(\Delta \mathrm{C})^{0.40} \\
& \mathrm{R}_{\mathrm{G}}=1.20 * 10^{-4}(\Delta \mathrm{C})^{0.67}
\end{aligned}
$$

Buradan görüldüğü üzere $-600+500 \mu \mathrm{m}$ boyut aralığı için büyüme hız mertebesi $0.40 \mathrm{iken},-710+600 \mu \mathrm{m}$ boyut aralığı için ise 0.67 olarak bulunmuştur. Tane boyutu arttıkça büyüme hız mertebesinin artması, bu tanecikleri akışkanlaştırma için gerekli olan akışkanlaşma hızının daha fazla olmasından kaynaklanmaktadır. Akışkanlaşma hızının artması da difüzyon tabakasını incelterek, bu tane boyutu için $(-710+600 \mu \mathrm{m})$ büyümenin $-600+500 \mu \mathrm{m}$ boyut aralığına göre biraz daha yüksek olmasına neden olmaktadır. Şekil 4'te deneylerde kullanılan iki farklı tane boyutundaki DAP kristallerinin 1şık mikroskobu altında çekilen görüntüleri verilmiştir. Şekil 4 incelendiğinde akışkan yatak kristalizörde saf ortamda büyütülen kristallerin, çok belirgin bir yapıya sahip olmamakla birlikte genel olarak küremsi kristaller olduğu, büyük tane boyutuna sahip olan kristallerde hafif çıkıntı yapıların olduğu görülmektedir. Daha detaylı taramalı elektron mikroskop görüntülerini içeren Gargouri vd. (2014) tarafından yapılan deneysel çalışmada, plot ölçekli kesikli kristalizörde 400-600 rpm karıştırma hızında elde edilen DAP kristallerinin morfolojisinin konik yapılı olduğu rapor edilmiştir [12]. Buradan anlaşıldığı üzere DAP kristallerinin morfolojisi, kristalizör tipi ve işletim koşulları ile ortam bileşiminden çok etkilenmektedir.

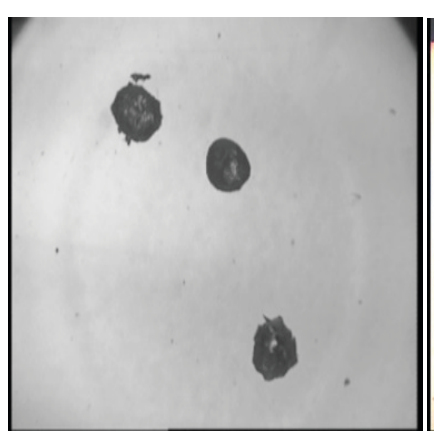

(a)

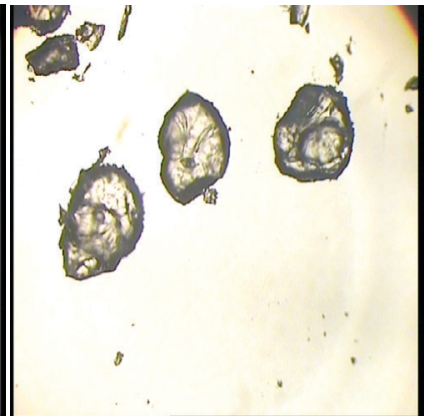

(b)
Şekil 4. Deneylerde büyütülen DAP kristalleri (a) $-600+500 \mu \mathrm{m}$, (b) $-710+600 \mu \mathrm{m}$
Bu çalışmada, önceki bölümlerde de belirtiği üzere, DAP kristallerinin büyüme ve çözünme hızlarına amino asitlerin etkisini incelemek amaciyla prolin ve asparajin amino asitleri kullanılmıştır. Prolinin katkı olarak etkisi, 250, 500 ve 1000 ppm derişimler için incelenmiştir. Elde edilen sonuçlar toplu olarak Şekil 5’te sunulmuştur.

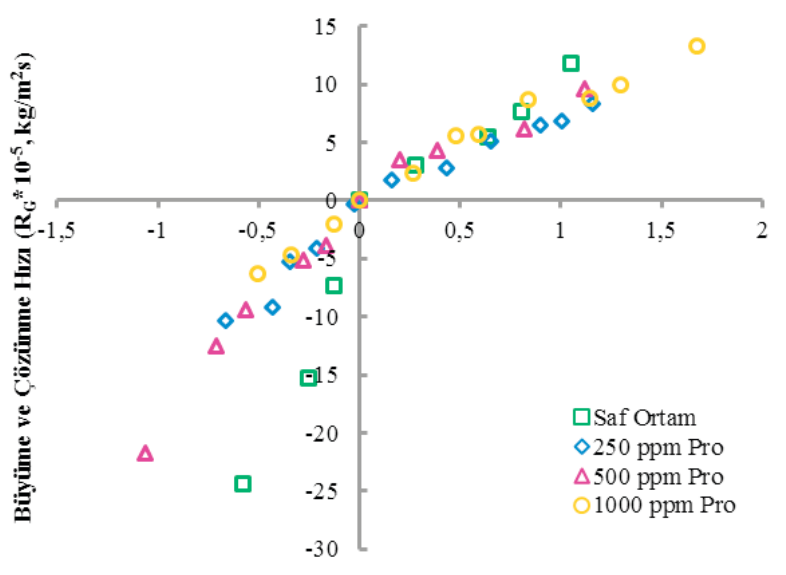

Așırı Doygunluk, $\Delta$ C (g DAP/100 g çözelti)

Şekil 5. DAP Çözünme ve Büyüme Hızına Prolin Etkisi

Şekil 5 'te verilen toplu sonuçlar incelendiğinde, prolin varlığında DAP kristallerinin büyüme hızının az da olsa bastırıldığ 1 görülmektedir. Burada prolinin derişimi açısından bakıldığında, 250 ppm prolin derişiminde DAP kristallerinin büyüme hızının oldukça bastırılmış olduğu; ancak prolin derişiminin artmasıyla bu eğilimin azalmış ve tekrar saf ortamdaki büyüme hızına yaklaşmış olduğu belirlenmiştir. Aşırı doygunluk oranı yüksek olduğunda tüm prolin derişimlerinde, büyümenin saf ortama göre daha yüksek oranda bastırıldığı görülmüştür. Çözünme hızı açısından prolinin etkisinin daha belirgin olduğu saptanmıştır. Prolin varlığında çözünme hızının, saf ortama göre oldukça fazla azaldığı tespit edilmiştir. Bunun yanında, Şekil 5'ten bu azalmanın prolinin konsantrasyonuna çok fazla bağlı olmadığı görülmektedir. Prolin varlığında büyütülen DAP kristallerinin 1 şık mikroskobu altında çekilmiş fotoğrafları Şekil 6'da verilmiştir. Buradan prolin varlığında büyütülmüş kristallerin saf ortama göre daha küresel hale geldiği, saf ortamda büyütülen kristallerde mevcut olan deformasyonların kaybolduğu görülmektedir. Şekil 6'dan görüldüğü üzere prolin derişimi arttıkça keskin kenarlı yüzeyler ve kristal yüzeylerinde yüzey nükleasyonu sonucu oluşabilecek bir takım birikimler ortaya çıkmaktadır. Bu durum ise büyüme hızında az da olsa artış olarak sonuçlara yansımıştır. 

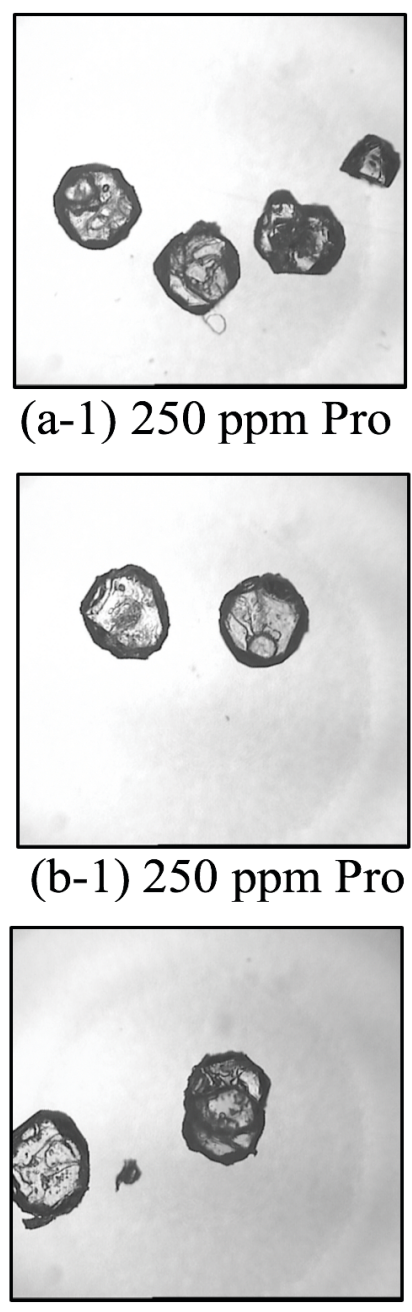

(c-1) 250 ppm Pro

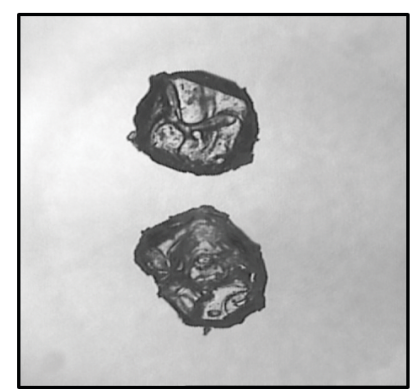

(a-2) 500 ppm Pro
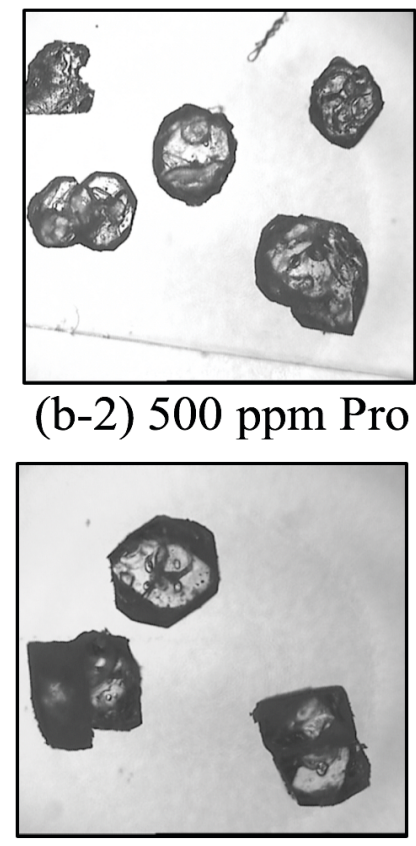

(c-2) 500 ppm Pro

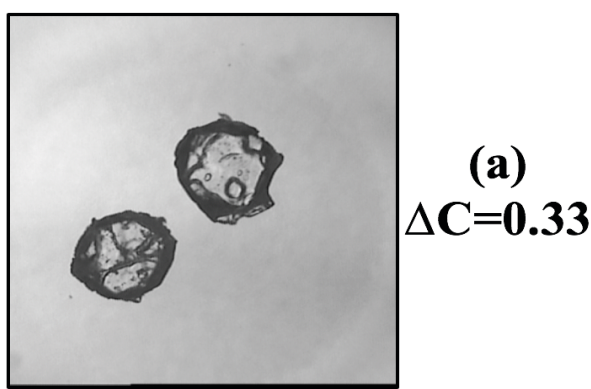

(a-3) 1000 ppm Pro

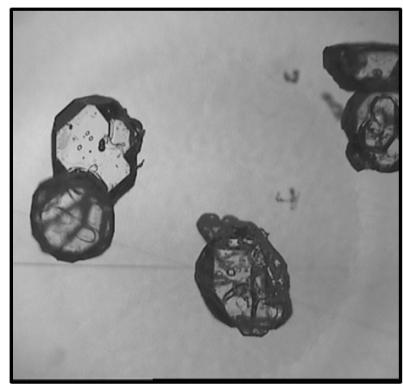

(b)

$\Delta \mathbf{C}=\mathbf{0 . 6 6}$

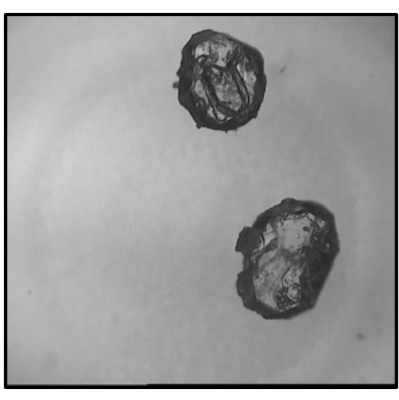

(c-3) 1000 ppm Pro

Şekil 6. Prolin varlığında büyüyen DAP kristallerinin farklı aşırı doygunluklarda ışık mikroskobu görüntüleri

Asparajin amino asidi varlığında yapılan deneylere ait büyüme ve çözünme hızı sonuçları toplu olarak Şekil 7'de gösterilmektedir. Toplu sonuçlardan görüldüğü üzere asparajin varlığında da büyüme hızı saf ortama göre biraz bastırılmış; çözünme hızı ise yine incelenen tüm asparajin derişimlerinde saf ortama göre belirgin bir şekilde azalmıştır. Şekil 7'den, düşük aşırı doygunluklarda büyüme hızının asparajin konsantrasyonundan bağımsız olduğu, ancak yüksek aşırı doygunluklarda asparajin derişiminin artmasıyla büyüme hızındaki bastırılma eğiliminin de arttığı görülmektedir. Çözünme hızındaki değişimler incelendiğinde, prolin varlığında olduğu gibi asparajin varlığında da çözünme hızının saf ortama göre önemli ölçüde azaldığ saptanmıştır. Ancak burada prolinden farklı olarak asparajin derişiminin artmasının, özellikle yüksek aşırı doymamışlıklarda, DAP çözünürlüğünü de arttırdığı tespit edilmiştir.

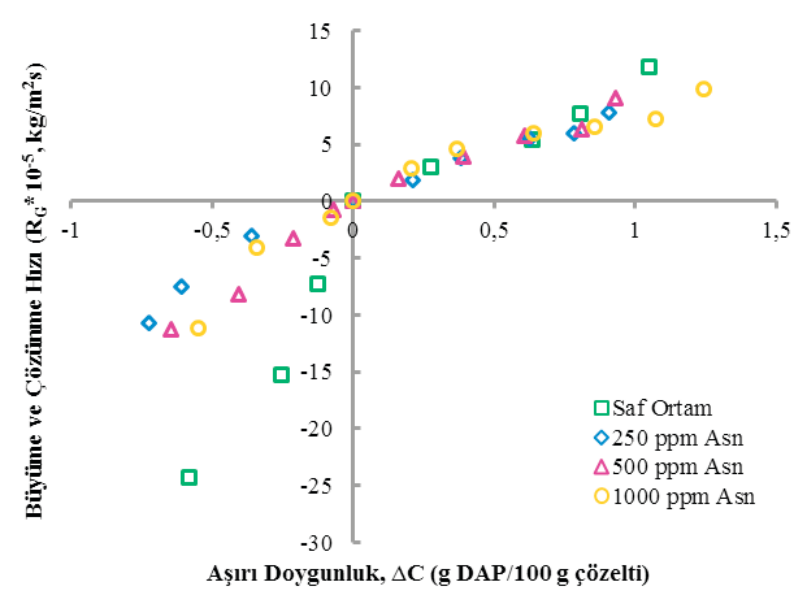

Şekil 7. DAP Çözünme ve Büyüme Hızına Asparajin Etkisi 
Asparajin varlığında elde edilen DAP kristallerinin 1 şık mikroskobundaki görüntüleri Şekil 8'de verilmiştir. Buradaki mikroskop görüntüleri incelendiğinde, asparajin varlığında büyüyen kristallerde prolin varlığında büyütülen kristallere göre, belirli noktalardan büyümenin daha fazla olduğu, ana gövdeden büyüyen ve keskin kenarlara sahip olan yüzeylerin etkin bir şekilde arttı̆g görülmüştür. Asparajin, yapısal olarak polar yan grubunun etkisiyle proline göre daha yüzey aktif bir amino asit olduğundan bu durum beklenen bir durumdur. Bunun sonucunda $250 \mathrm{ppm}$ amino asit katkılı ortamda, tüm aşırıdoygunluk oranlarında asparajin varlığında büyüme hızlarının prolin varlığındakilere göre daha yüksek değerlerde olduğu bulunmuştur. Bunun yanında, 500 ppm ve 1000 ppm amino asit derişimlerinde düşük aşırı doygunluklarda, iki amino asit varlığında da büyüme hızları birbirine yakın değerlerde ölçülmüştür. Ancak yüksek aşırı doygunluklarda 500 ppm için asparajin varlığında kristal büyüme hızlarının prolin varlığındakilere göre biraz daha yüksek olduğu; 1000 ppm için ise durumun tam tersine döndüğü, yani prolin varlığında kristal büyüme hızlar1nın asparajin varlığındakilere göre daha yüksek olduğu tespit edilmiştir. Bunun nedeni olarak, yüksek amino asit derişimlerinde aktif yan zinciri sayesinde asparajinin, DAP kristallerinin yüzeyindeki tüm aktif büyüme bölgelerini doldurduktan sonra, çözelti içerisinde kendisi gibi polar moleküllerle $\left(\mathrm{H}_{2} \mathrm{O}\right.$ vb.) etkileşime girmesi ve sonuçta kristallerin büyümesini önemli ölçüde baskılaması şeklinde önerilebilir. Prolinin yan zinciri apolar ve hidrofob olduğu için $\mathrm{H}_{2} \mathrm{O}$ molekülleri ile asparajin gibi bir etkileşime girmeyeceğinden, prolinin yüksek derişimlerinde DAP kristallerinin yüzeyine toplanma eğilimi beklenmektedir.

Literatürde doğrudan DAP krsitallerinin üzerinde amino asitlerin etkisini inceleyen bir çalışmaya rastlanmamakla birlikte, genel olarak inorganik tuzların krsitalizasyonuna amino asitlerin morfolojik etkisinin, kristal yapıyı daha kararlı hale getirme ve morfolojiyi düzenleme şeklinde olduğu pekçok araştırmada ortaya konulmuştur. Örneğin Li Yao vd. (2010) tarafindan yapılan araştırmada, kalsiyum karbonat $\left(\mathrm{CaCO}_{3}\right)$ kristallerine aspartik asit ve arjinin amino asitlerinin etkisi incelenmiş ve burada saf kalsiyum karbonat kristallerinin amino asitlerin varlığında daha kompakt ve kararlı yapılara dönüştüğü ortaya konulmuştur [13].

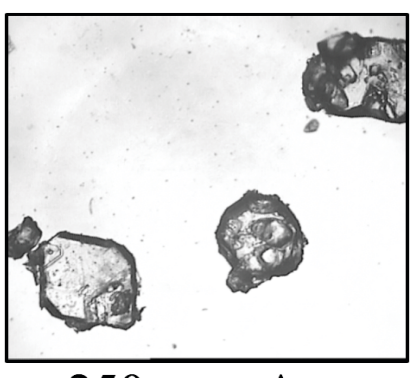

250 ppm Asn

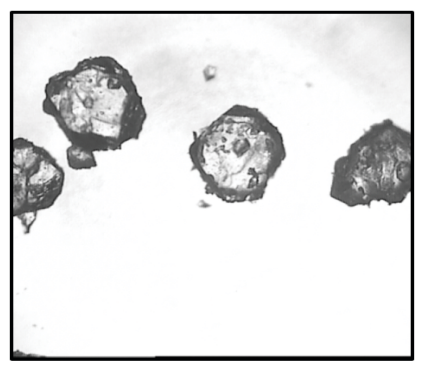

250 ppm Asn

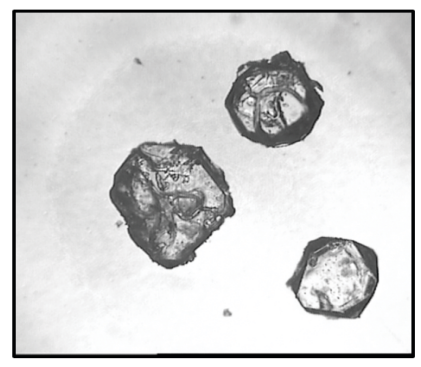

250 ppm Asn

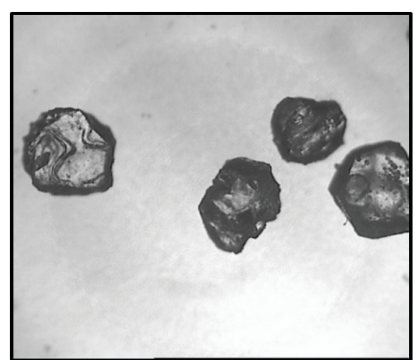

500 ppm Asn

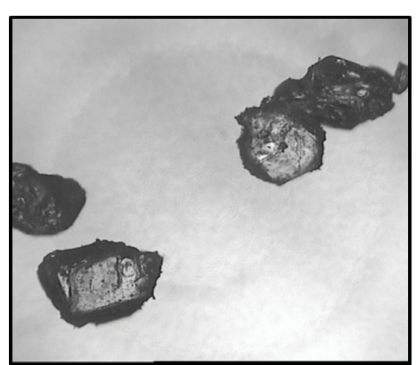

500 ppm Asn

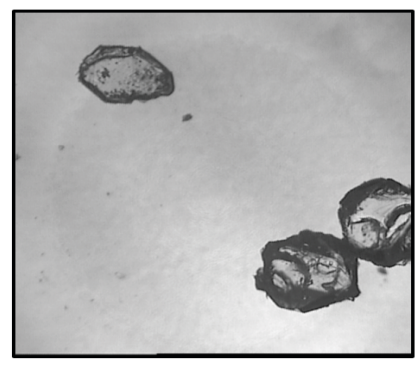

500 ppm Asn

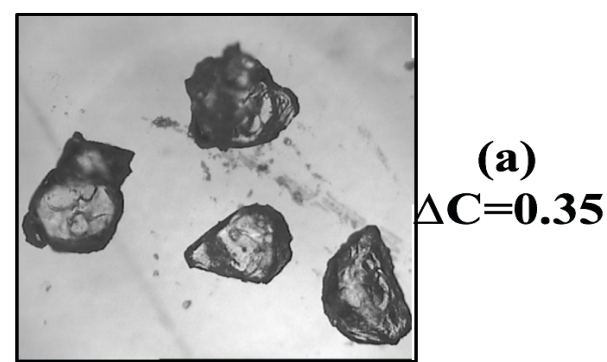

1000 ppm Asn

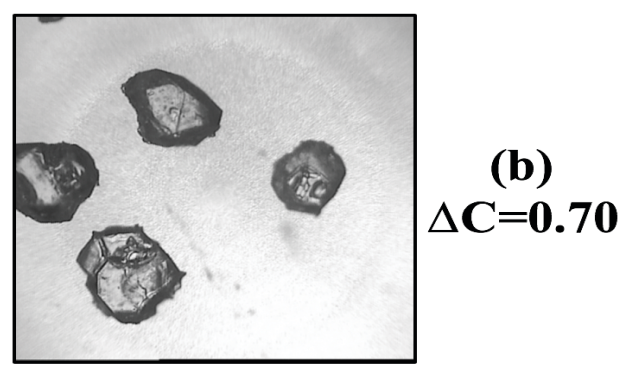

1000 ppm Asn

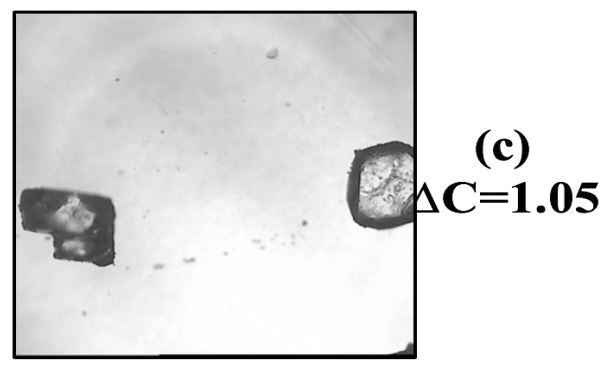

1000 ppm Asn

Şekil 8. Asparajin varlığında büyüyen DAP kristallerinin farklı aşırı doygunluklarda ışık mikroskobu görüntüleri 
Difüzyon hız sabiti $\left(\mathrm{k}_{\mathrm{D}}\right)$, hem saf ortam hem de amino asit katkılı ortamlar için Eşitlik (5) kullanılarak hesaplanmıştır. Entegrasyon hiz sabiti $\left(\mathrm{k}_{\mathrm{r}}\right)$ ve entegrasyon derecesi ( $\mathrm{r}$ ) parametreleri Eşitlik (4)'e, deneysel verilere göre eğri uydurma yöntemi uygulanarak Matlab'de saptanmıştır. Hesaplanan kinetik parametreler Tablo 1'de sunulmuştur. Tablo 1'den görüldüğü üzere amino asit varlığında, DAP kristalleri için hem difüzyon hem de entegrasyon hız sabiti genel olarak azalmaktadır. Bunun yanında yüzey entegrasyonunun aşırı doygunluğa bağlılığının bir göstergesi olan entegrasyon derecesinin de amino asit varlığında, genel olarak azaldığı tespit edilmiştir.

Tablo 1. Difüzyon ve entegrasyon hız parametreleri

\begin{tabular}{lllll}
\hline & $\begin{array}{l}\text { Derişim } \\
(\mathbf{p p m})\end{array}$ & $\mathbf{k}_{\mathrm{D}}\left(* \mathbf{1 0}^{-4}, \mathbf{k g} / \mathbf{m}^{2} \mathbf{s}\right)$ & $\mathbf{k}_{\mathrm{r}}\left(* \mathbf{1 0} \mathbf{0}^{-4}, \mathbf{m} / \mathbf{s}\right)$ & $\mathbf{r}$ \\
\hline Saf Ortam & 0 & 4.42 & 2.14 & 0.91 \\
\hline \multirow{4}{*}{ Prolin } & 250 & 2.00 & 1.27 & 0.88 \\
& 500 & 1.97 & 1.53 & 0.54 \\
& 1000 & 1.40 & 2.22 & 0.45 \\
\hline \multirow{4}{*}{ Asparajin } & 250 & 2.53 & 1.61 & 0.94 \\
& 500 & 2.31 & 1.62 & 0.67 \\
& 1000 & 2.48 & 1.66 & 0.65 \\
\hline
\end{tabular}

Kristal büyümesine difüzyon ve yüzey entegrasyonu basamaklarının etkisini nicel olarak ortaya koymak üzere önceki bölümlerde açıklanan etkinlik faktörü kullanılmıştır. Nicel anlamları açısından Da değeri büyük olduğunda, büyüme difüzyon kontrollü olmaktadır ve entegrasyon etkinlik faktörü $\left(\eta_{\mathrm{r}}\right)$ ' 'a yaklaşmaktadır. Tam tersi Da değeri küçük olduğunda, $\eta_{\mathrm{r}} 1$ 'e yaklaşmaktadır ve büyüme entegrasyon adımı tarafindan kontrol edilmektedir. Saf ortamda ve amino asit katkılı ortamlarda DAP kristallerinin büyümesi için Da ve $\eta_{\mathrm{r}}$ değerleri farklı aşırı doygunluk seviyelerine göre hesaplanmıştır ve sonuçlar Tablo 2 ve Tablo 3 'te sunulmuştur. Buradaki entegrasyon etkinlik faktörü $\left(\eta_{\mathrm{r}}\right)$ değerlerinden, tek bir adımın kristal büyümesini kontrolünden söz etmek mümkün değildir. DAP kristallerinin hem saf ortamda hem de amino asit katkılı ortamlarda büyümesini kontrol eden mekanizmaya difüzyon ve entegrasyon adımlarının etki ettiği görülmektedir.

$\mathrm{Bu}$ çalışmada elde edilen sonuçlardan, her iki amino asit varlı̆̆ında da büyümenin saf ortama göre baskılandığı saptanmıştır. Saf ortamda DAP kristallerinin büyümesinde hız kontrol

Tablo 2. Saf Ortamda ve prolin varlığında DAP kristallerinin büyümesi için Da ve $\eta_{\mathbf{r}}$ değerlerinin aşırı doygunlukla değişimi

\begin{tabular}{|c|c|c|c|c|c|c|c|c|c|c|c|}
\hline \multicolumn{3}{|c|}{ SAF } & \multicolumn{3}{|c|}{$250 \mathrm{ppm}$} & \multicolumn{3}{|c|}{500 ppm } & \multicolumn{3}{|c|}{1000 ppm } \\
\hline$\Delta C(g / 100 \mathrm{~g}$ çöz. $)$ & Da & $\eta_{\mathrm{r}}$ & $\Delta C$ (g/100 g çöz.) & Da & $\eta_{\mathrm{r}}$ & $\Delta C$ (g/100 g çöz.) & Da & $\eta_{\mathrm{r}}$ & $\Delta C(g / 100 \mathrm{~g}$ çöz. $)$ & Da & $\eta_{\mathrm{r}}$ \\
\hline 1.075 & 0.482 & 0.692 & 1.139 & 0.626 & 0.639 & 1.209 & 0.713 & 0.692 & 1.226 & 1.418 & 0.532 \\
\hline 0.832 & 0.493 & 0.687 & 0.894 & 0.645 & 0.632 & 0.91 & 0.813 & 0.66 & 0.922 & 1.659 & 0.483 \\
\hline 0.661 & 0.503 & 0.682 & 0.4 & 0.713 & 0.608 & 0.482 & 1.089 & 0.582 & 0.678 & 1.964 & 0.431 \\
\hline 0.303 & 0.54 & 0.666 & 0.244 & 0.759 & 0.593 & 0.29 & 1.375 & 0.515 & 0.35 & 2.828 & 0.325 \\
\hline
\end{tabular}

Tablo 3. Saf Ortamda ve asparajin varlığında DAP kristallerinin büyümesi için Da ve $\eta_{\mathrm{r}}$ değerlerinin aşırı doygunlukla değişimi

\begin{tabular}{|c|c|c|c|c|c|c|c|c|c|c|c|}
\hline \multicolumn{3}{|c|}{ SAF } & \multicolumn{3}{|c|}{$250 \mathrm{ppm}$} & \multicolumn{3}{|c|}{$500 \mathrm{ppm}$} & \multicolumn{3}{|c|}{1000 ppm } \\
\hline$\Delta C(\mathrm{~g} / 100 \mathrm{~g}$ çöz. $)$ & Da & $\eta_{\mathrm{r}}$ & $\Delta \mathrm{C}(\mathrm{g} / 100 \mathrm{~g}$ çöz. $)$ & Da & $\eta_{\mathrm{r}}$ & $\Delta \mathrm{C}$ (g/100 g çöz.) & Da & $\eta_{\mathrm{r}}$ & $\Delta C$ (g/100 g çöz.) & Da & $\eta_{\mathrm{r}}$ \\
\hline 1.075 & 0.482 & 0.692 & 1.204 & 0.629 & 0.625 & 1.143 & 0.672 & 0.67 & 1.176 & 0.63 & 0.69 \\
\hline 0.832 & 0.493 & 0.687 & 0.715 & 0.649 & 0.618 & 0.823 & 0.749 & 0.644 & 0.743 & 0.741 & 0.652 \\
\hline 0.661 & 0.503 & 0.682 & 0.473 & 0.666 & 0.612 & 0.606 & 0.829 & 0.618 & 0.469 & 0.87 & 0.611 \\
\hline 0.303 & 0.54 & 0.666 & 0.245 & 0.692 & 0.602 & 0.086 & 0.096 & 0.930 & 0.086 & 0.110 & 0.931 \\
\hline
\end{tabular}

mekanizmasında hem entegrasyonun hem de difüzyonun etkisinin olduğu; ancak entegrasyonun difüzyonuna göre biraz daha yüksek etkiye sahip olduğu görülmüştür (Tablo 4). Prolin varlığında DAP kristalleri büyürken, prolin derişiminin artmasıyla difüzyon etkisinin de artmaya başladığı ve yüksek prolin derişiminde saf ortama göre durumun tersine döndüğü, artık difüzyon adımının daha etkin olmaya başladığı saptanmıştır. Bununla yanında entegrasyon etkisinin, azalarak da olsa devam ettiği belirlenmiştir. Asparajin varlığında DAP kristalleri büyürken, difüzyon etkinliğinin biraz arttığı tespit edilmiş, ancak bu artış sonucunda hem difüzyon hem de entegrasyon adımlarının büyüme üzerinde etkinlik oranı neredeyse eşit hale gelmiştir. Ayrıca bu etki, tüm asparajin derişimlerinde yaklaşık olarak aynı kalmıştır. Sonuç olarak, amino asitlerin varlığında yüzey entegrasyonunun biraz daha kolaylaştığı ve özellikle prolinin yüksek derişiminde difüzyon adımının etkinliğinin belirgin bir şekilde arttığ 1 tespit edilmiştir.

Tablo 4. Difüzyon ve yüzey entegrasyonu adımlarının DAP kristallerinin büyümesine katılım yüzdesi

\begin{tabular}{lllll}
\hline \multirow{2}{*}{ Katkı (ppm) } & \multicolumn{2}{c}{ Prolin } & \multicolumn{2}{c}{ Asparajin } \\
\cline { 2 - 5 } & \% Ent. & \% Dif. & \% Ent. & \% Dif. \\
\hline 0 & 64.2 & 35.8 & 64.2 & 35.8 \\
250 & 59.4 & 40.6 & 60.3 & 39.7 \\
500 & 50.8 & 49.2 & 54.4 & 45.6 \\
1000 & 34.8 & 65.2 & 55.6 & 44.4 \\
\hline
\end{tabular}




\subsection{Sonuç ve Değerlendirmeler}

Prolin ve asparajin amino asitlerinin DAP kristallerinin büyüme ve çözünme hızlarına etkisinin incelendiği bu çalışmada, büyüme hızlarının incelenen amino asitler varlığında az da olsa bastırıldığı görülmüştür. Büyüme hız mertebeleri ve hız sabitleri hesaplanmıştır. Büyüme hızı kullanılarak, difüzyon ve yüzey entegrasyonu basamaklarının etkinliklerini, karşlaştırmalı olarak ortaya koyabilmek için etkinlik faktörleri hesaplanmıştır. Etkinlik faktörü sonuçlarına göre, saf ortamda ve amino asit içeren ortamlarda DAP kristallerinin büyüme hızının kontrol mekanizmasını difüzyon ve yüzey entegrasyonu basamaklarının etkilediği açıkça görülmektedir. Prolinin yüksek derişimi haricinde, yüzey entegrasyonunun biraz daha etkin olduğu anlaşılmaktadır. Burada katkı maddeleri varl1ğında, DAP kristallerinin büyüme hızı üzerinde difüzyon etkinliğinin arttı̆̆ ve bu etkinin en belirgin olarak Prolin amino asitinin yüksek konsantrasyonunda olduğu görülmüştür.

$\mathrm{Bu}$ çalışmada, prolin ve asparajin amino asitlerinin DAP kristallerinin çözünme hızlarına önemli derecede etkisinin olduğu saptanmıştır. Öyle ki her iki amino asit için de incelenen tüm durumlarda, DAP kristallerinin çözünme hızı saf ortama göre belirgin bir şekilde azalmıştır. Bu etkinin, kontrollü ve yavaş salınımlı gübre üretiminde dikkate alınabilecek nitelikte olduğu düşünülmektedir. Amino asitlerin katkısıyla DAP kristallerinin büyümesini ve çözünmesini kontrol etmek suretiyle, istenen ürün spesifikasyonlarının sağlanması dikkat çekici bir alternatif olarak görünmektedir.

Ayrıca, 1şık mikroskopu altında çekilen fotoğraflar göstermiştir ki, amino asitler varlığında büyütülen DAP kristallerinin morfolojisi saf ortama göre belirgin şekilde değişmiştir. $\mathrm{Bu}$ amino asitlerin varlığında büyüyen kristallerin, saf ortama göre çok daha düzgün ve keskin yüzeylere sahip olduğu tespit edilmiştir. Kristalizasyon proseslerinde kristal şeklinin, ürünün mekanik mukavemeti, döküm yoğunluğu ve kekleşme gibi kristal ürünün kalitesini belirleyen özelliklerini etkilediği düşünülürse, gübre amaçlı kullanılacak DAP üretiminde amino asitlerin kullanımının olumlu etki yapacağı açıktır. Ancak bunun için kristallerin dayanıklılığının da tespit edilmesi gerekmektedir.

\section{KAYNAKLAR}

[1] Toy, A. D. F., The Chemistry of Phosphorus, Pergamon Press, New York, 1973.

[2] Gübrelerin Sinıflandirılması, http:// www.tarimkutuphanesi. com /GUBRELERIN_SINIFLANDIRILMASI_00276, (Aralık 2018).

[3] Nurcebi, A., 8 Temel Aminoasit, Türkiye https://aminoasitblog.wordpress.com/2015/02/17/8-temel-amino-asit/, (Mart 2015).
[4] Olgun, M., Başçiftci Z.B., Ayter , N.G., Turan, M., Aydın, D., Şaban, Z., Sönmez, A.C., Koyuncu, O. (2016). Potasyum Iyodür Uygulamasının Ekmeklik Buğday Çeşiterinin Biyokimyasal Özellikleri Üzerine Etkisi, Süleyman Demirel Üniversitesi Ziraat Fakültesi Dergisi 11 (2):46-60.

[5] Wang, G., Zhang, J., Wang, G., Fan, X., Sun, X., Qin, H., Xu, N., Zhong, M., Qiao, Z., Tang, Y. and Song, R. (2014). Proline responding1 Plays a Critical Role in Regulating General Protein Synthesis and the Cell Cycle in Maize, The Plant Cell, Vol. 26: 2582-2600.

[6] Robert K. Murray, Daryl K. Granner, Peter A. Mayes, Victor W. Rodwell. Harper's Biochemistry, Mc Graw Hill, USA, 2000.

[7] Mullin, J.W., (2001). Crystallization, 4th Ed., Butterworth Heinmann, Oxford, p 225-228.

[8] Al-Jibbouri, S. And Ulrich, J. (2001). The growth and dissolution of sodium chloride in a fluidized bed crystallizer, Journal of Crystal Growth, 234 (2002) 237-246.

[9] Titiz-Sargut, S. (1997). Sodyum Perborat Kristalizasyonuna Polielektrolitlerin Etkisi, Doktora Tezi, İstanbul Teknik Üniversitesi, Istanbul.

[10] Al-Jibbouri, S. (2002). Effects of Additives in Solution Crystallization, $\mathrm{PhD}$ Thesis, Martin Luther University, Merseburg, Germany.

[11] Badem, G. (2004). Potasyum Perborat Oktahidratın Kristal Büyüme ve Çözünme Hızlarının Akışkan Yataklı Ölçüm Sisteminde İncelenmesi, Y.Lisans Tezi, İstanbul Teknik Üniversitesi, Istanbul.

[12] Gargouri, M., Chtara, C., Sharrock, P., Nzihou, A., El Feki, H.(2014). Purification of an Industrial Fertilizer (Diammonium Phosphate) Using Design of Experiments, International Journal of Materials Engineering, 4(6): 185-191.

[13] Li-Yao, C., Qi, C.-X., Zhu, J.-M., Xu, A.-H. (2010). Unusual Morphology of Calcium Carbonate Controlled By Amino Acids in Agarose Gel, J. Chil. Chem. Soc, 55 (2), 270-273.

\section{SIMMGELER}

$\mathrm{C}^{*} \quad$ : Doygunluk derişimi $\left(\mathrm{kg} / \mathrm{m}^{3}\right)$

$\mathrm{C}^{\mathrm{b}} \quad$ : Yı̆̆ın Derişimi $\left(\mathrm{kg} / \mathrm{m}^{3}\right)$

$\mathrm{C}_{\mathrm{i}} \quad$ : Arayüzey derişimi $\left(\mathrm{kg} / \mathrm{m}^{3}\right)$

$\Delta \mathrm{C} \quad$ : Aşırı doygunluk $\left(\mathrm{g}_{\text {katı }} / 100 \mathrm{~g}_{\text {çö }}\right)$

$\mathrm{D}_{\mathrm{a}} \quad$ : Damköhler sayısı (Boyutsuz)

G : Toplam lineer büyüme hızı (m/sn)

g : Büyüme hız derecesi (Boyutsuz)

$\mathrm{k}_{\mathrm{d}} \quad$ : Difüzyon kütle transfer katsayısı ya da çözünme hız sabiti $(\mathrm{m} / \mathrm{sn})$

$\mathrm{k}_{\mathrm{G}} \quad$ : Toplam büyüme hız sabiti $\left(\left(\mathrm{kg} / \mathrm{m}^{2} \mathrm{~s}\right)\left(\mathrm{kg} / \mathrm{m}_{\text {ç̈z }}^{3}\right)^{-\mathrm{g}}\right)$

$\mathrm{k}_{\mathrm{r}} \quad$ : Büyüme entegrasyon hız sabiti ya da yüzey tepkimesi hız sabiti $\left(\left(\mathrm{kg} / \mathrm{m}^{2} \mathrm{~s}\right)\left(\mathrm{kg} / \mathrm{m}_{\text {çӓ̆ }}^{3}\right)^{-\mathrm{r}}\right)$

$\mathrm{L}_{1} \quad$ : Başlangıç kristal boyu (m)

$\mathrm{L}_{2} \quad$ : Son kristal boyu (m) 
$\mathrm{m}_{1} \quad$ : Başlangıç kristal ağırlı̆̆ $1(\mathrm{~g})$

$\mathrm{m}_{2} \quad$ : Son kristal ağırlı̆̆ $(\mathrm{g})$

$\mathrm{R}_{\mathrm{D}}$ : Çözünme hızı $\left(\mathrm{kg} / \mathrm{m}^{2} \mathrm{~s}\right)$

$\mathrm{R}_{\mathrm{G}} \quad$ : Toplam kütle büyüme hızı $\left(\mathrm{kg} / \mathrm{m}^{2} \mathrm{~s}\right)$

$r \quad$ : Entegrasyon (yüzey tepkimesi) prosesinin derecesi (boyutsuz)

t : zaman (sn)

$\mathrm{r}_{\mathrm{L}} \quad$ : Çözelti yoğunluğu $\left(\mathrm{kg} / \mathrm{m}^{3}\right)$

$\mathrm{r}_{\mathrm{C}} \quad$ : Kristal yoğunluğu $\left(\mathrm{kg} / \mathrm{m}^{3}\right)$

a : Hacim şekil faktörü

b : : Yüzey şekil faktörü

$\eta_{\mathrm{d}} \quad$ : kristal büyümesi için difüzyon etkinlik faktörü

$\eta_{\mathrm{r}} \quad$ : kristal büyümesi için yüzey entegrasyonu etkinlik faktörü 